METALLURGY AND FOUNDRY ENGINEERING - Vol. 36, 2010, No. 1

Jadwiga Kamińska*, Joanna Kolczyk*, Sylwia Żymankowska-Kumon*

\title{
EFFECT OF GRAIN SIZE OF THE RECLAIMED MATRIX CERAMIC MOULDS USED IN THE LOST WAX TECHNOLOGY ON THE STRENGTH AT HIGH TEMPERATURE
}

\section{INTRODUCTION}

Shell, multi-layered moulds are used in an investment casting method. Production of ceramic moulds for investment casting by means of an investment casting method is based on a cyclic process of a wax model immersion in a liquid ceramic sand, powder topping with ceramic material of various grain coarseness followed by drying of the formed layer, until the required thickness and mechanical strength of the layered casting mould is obtained. At the end of this process the wax model is removed by melting. The quality of casting moulds as well as the quality of castings produced in such moulds strongly depends on a binding agent being a component of a liquid ceramic sand.

The basic binding agent used in the investment casting for higher quality castings was - from the very beginning of the development of this method - hydrolysed ethyl silicate. On account of the regulations related to the environment protection attempts are undertaken to eliminate this kind of a binder and substituting it by a binding agent in which water is a solvent.

Hardening of a ceramic mould in a technology applying water solution of colloidal silica is mainly based on drying. The hardening process of thin ceramic layers is accelerated by an application of powder toppings, of a coarse matrix. This causes an external surface expansion, which significantly facilitates a water evaporation from colloidal silica [6].

The results of investigations concerning a determination of dependence between a size of grains used for powder toppings and a tensile strength under a wet condition are presented in this paper. Examinations were carried out with using fresh powder toppings and reclaimed materials from worn ceramic moulds.

* M.Sc.: Faculty of Foundry Engineering, AGH - University of Science and Technology, Krakow, Poland; e-mail: szk@agh.edu.pl 


\section{INVESTIGATIONS}

The aim of the performed examinations was to determine an influence of grains used for powder toppings on the tensile strength under a wet condition. Reclaimed and fresh ceramic sands were used as the matrix of the mould. The fresh material of fractions: $\mathrm{d}_{\mathrm{L}}=0.20 ; 0.32$ and $0.73 \mathrm{~mm}$.

Worn ceramic moulds were crushed before the reclamation process. The reclamation process was carried out by means of the testing apparatus for the mechanical reclamation constructed in the Laboratory of Foundry Machines and Casting Design of the Faculty of Foundry Engineering, the University of Science and Technology, AGH in Krakow.

The reclaimed material, obtained after the reclamation process, was undergoing a sieve analysis and estimation of grain shapes. The sieve analysis was done to fractionalise the reclaimed material into individual grain sizes. The reclaimed material of fractions: $\mathrm{d}_{\mathrm{L}}=0.2 ; 0.4$ and $0.63 \mathrm{~mm}$ were applied in examinations. The coatings were deposited on the properly prepared sample. The next stage of examinations was the preparation of ceramic moulds for the tensile strength measurements under wet conditions.

\subsection{Methodology of preparing samples for measuring strength under wet conditions}

The core, which was used for making the mould layer undergoing rupture was of a roll - divided at a half of its length - shape. It was acting as a wax model, on which a multi-layer ceramic mould is being made. The sample with the deposited ceramic sand layer is shown in Figure 1. It is made in a few cycles: deposition of ceramic sand and powder topping with grain matrix.

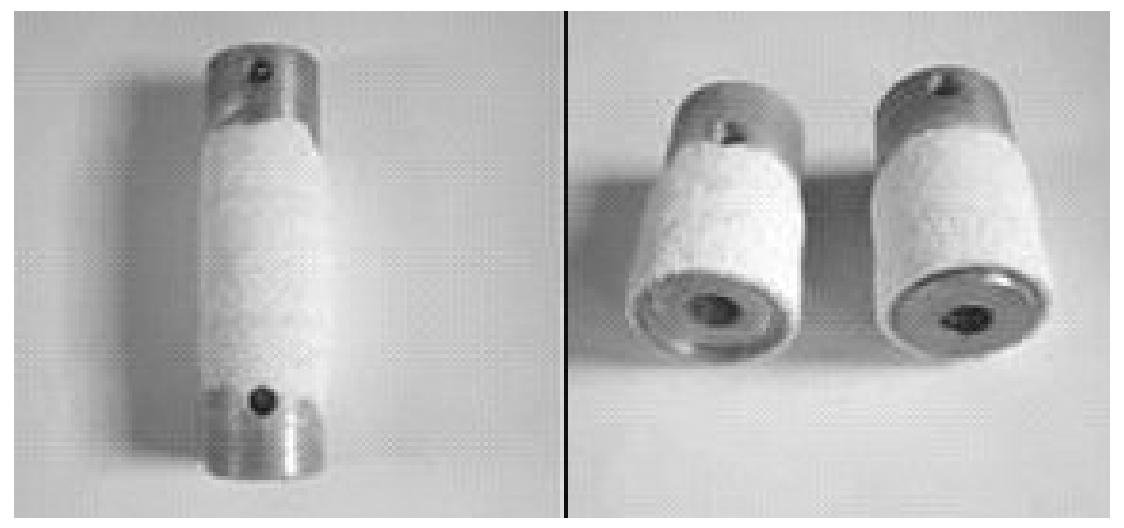

Fig. 1. Divided sample of a roll shape after deposition of the ceramic layer, before and after the rupture

Two coatings were deposited on the properly prepared sample. After each deposition of a ceramic sand a powder topping was placed on roll models. This powder was made of 
the reclaimed sands of the grain size: $d_{L}=0.20,0.40$ and $0.63 \mathrm{~mm}$, respectively. In order to shorten a cooling time, sampled were dried under conditions of a forced air circulation. Samples were ruptured after 18 hours from depositing the second layer.

\subsection{Tensile strength tests}

Tensile strength $\mathrm{R}_{\mathrm{m}}$ is determined as the ratio of the tensile force, which caused the sample rupture, to the initial cross-section of the sample, it means in the place of the smallest cross-section. Measurements were carried out on the universal equipment for testing strength of moulding sands. Sample of a roll shape with the deposited ceramic layer is being placed in special holders of the testing machine - during the measurements (Fig. 2). Clamping in the machine enables sample stretching in a vertical position.

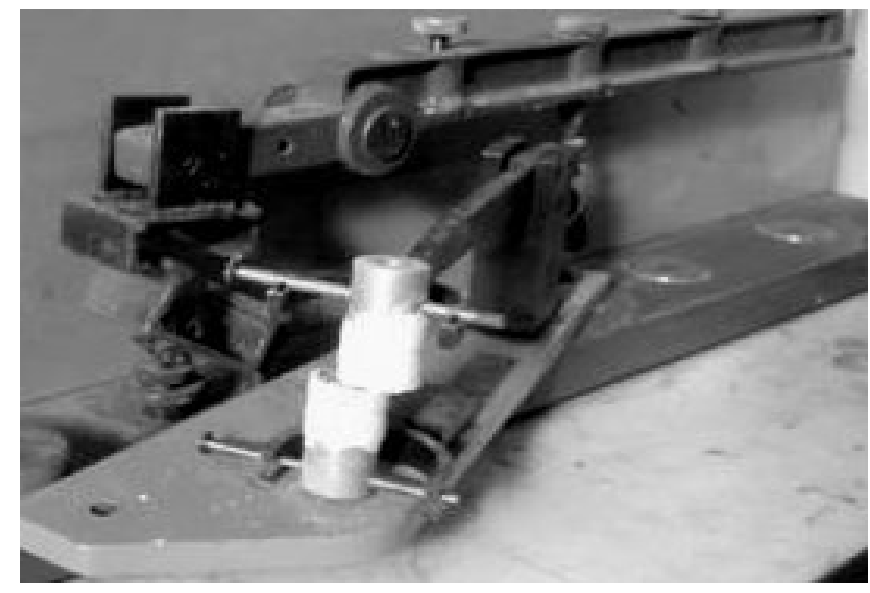

Fig. 2. Testing machine with a sample

Operation of the compound lever causes that the upper and bottom part of the divided sleeve are pulled off from each other with increasing force up to a moment of a total rupturing of the ceramic layer. The obtained result is read from the scale. Then the area of the ceramic mould layer in the place of rupturing is measured. Stress values causing the sample rupturing is determined from the ratio of the force to the ruptured area of the stretched sample.

\section{OBTAINED RESULTS OF THE STRENGTH UNDER WET CONDITIONS: „GREEN STRENGTH”}

The obtained results of the ceramic mould strength under wet conditions are presented in Figure 3. It is seen, that the grain size has a strong influence on the tensile strength of the sample in a wet state. When the grain size of the matrix increases the "green strength" decreases. A similar relationship was obtained for reclaimed matrix grain size. 


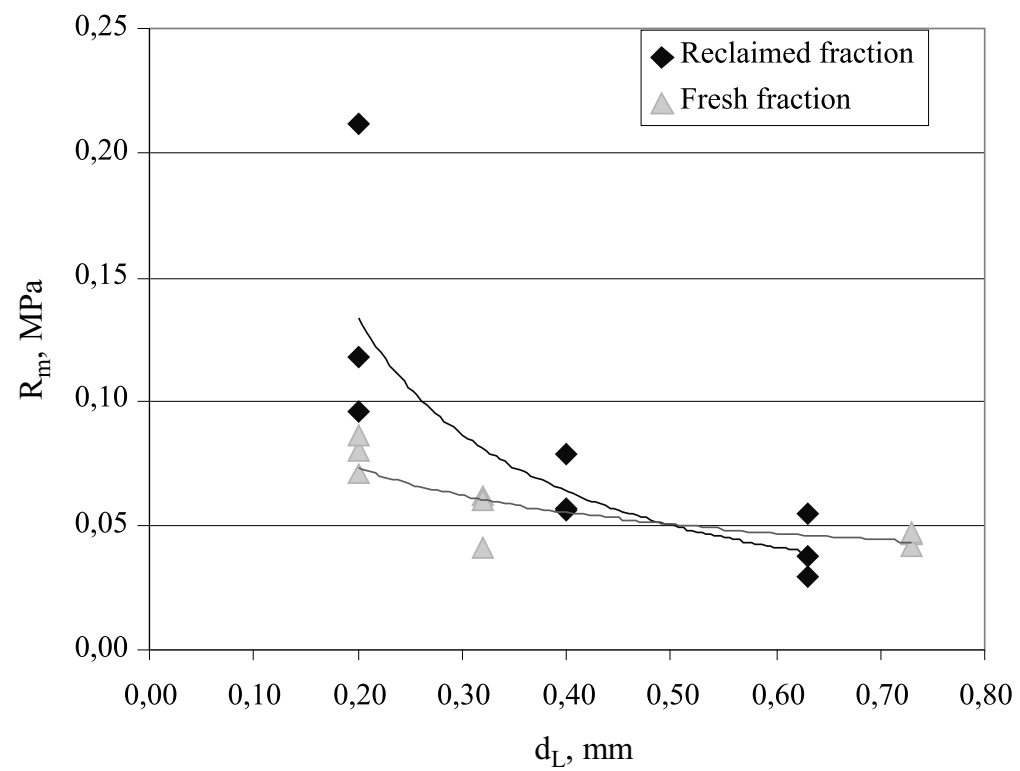

Fig. 3. Comparison of influence of reclaimed and fresh matrix grain size of the ceramic mould on the tensile strength under wet conditions

\section{CONCLUSIONS}

The influence of the ceramic matrix grain size (colloquially called a powder topping) on the strength of moulds applied in the investment casting technology - was determined.

The strength under wet conditions decreases when the matrix grain size increases. The strength for fresh matrix grain size decreases by approximately $30 \%$ at $\mathrm{d}_{\mathrm{L}}$ increased from $0.20 \mathrm{~mm}$ to $0.73 \mathrm{~mm}$. The strength for reclaimed matrix grain size decreases by approximately $70 \%$ at $\mathrm{d}_{\mathrm{L}}$ increased from $0.20 \mathrm{~mm}$ to $0.63 \mathrm{~mm}$. The differences are probably due to different grain shapes.

\section{Acknowledgements}

This study was performed within the Research Project MNiSW No. PBZ-MNiSW-03/I/ 2007 (2007-2010).

\section{REFERENCES}

[1] Dańko R., Kamińska J.: Assessment of the reclamation of used sands from the alpha-set technology in the testing apparatus, Archives of Foundry Engineering, 9 (2009) 1, 33-37

[2] Holtzer M.: Materiały II Sympozjum Naukowego Wykonawców PBZ-MNiSW-03/I/2007, Rzeszów, 1516.12.2009 (unreported work)

[3] Lewandowski J.L.: Materiały formierskie, Laboratorium, UWN-D Wydawnictwo AGH, Kraków, 1997 
[4] Lewandowski J.L.: Materiały Formierskie. Badania - cześć I, UWN-D Wydawnictwo AGH, Kraków, 1990

[5] Lewandowski J.L.: Tworzywa na formy odlewnicze, Wyd. Nauk. „Akapit ”, Kraków, 1997

[6] Sarek D.: Opracowanie metodyki badania właściwości technologicznych nowych, ekologicznych tworzyw stosowanych na formy ceramiczne w WSK „PZL-Rzeszów” S.A. AGH, Kraków, 2005 (praca magisterska)

[7] Zych J.: Koncepcja badania wytrzymałości powłok ceramicznych stosowanych w technologii pełnej form i wytapianych modeli. Wyd. XII Międz. Konf. Nauk.-Techn. Odlewnictwa Metali Nieżelaznych, Iwonicz, 4-6 czerwca 2009

[8] Zych J.: Raport z badań wykonywanych w ramach projektu MNiSW Nr PBZ-MNiSW-03/I/2007, 20082009 (unreported work)

Received

June 2010 